\title{
Comparison of two plain radiographic and 3D-based measurement methods for posterior malleolar fragment size in trimalleol ankle fractures
}

\author{
Trimalleoller ayak bileği kırıklarında posterior malleol fragmanın ölçümü için 3D \\ temelli ölçüm metodlarıyla ile iki boyutlu radyoragrafi metodunun karşılaştırılması
}

\author{
Güray Altun ${ }^{1}$, Hatice Çatal Reis ${ }^{2}$, Bülent Bayram ${ }^{3}$, Gürsel Saka ${ }^{4}$
}

Abstract

Aim: The aim of this study is, to compare the posterior malleolar fragment (PMF) sizing between lateral ankle radiography measurement and computer assistted 3D modelling (CA3DM) methods

Methods: Fifty-one patients between january 2015 and november 2018 with posterior malleolar fractured were included in this study. The rate of PMF to the articular surface at the distal end of the tibia was calculated by two different imaging methods by two surgeons. According to posterior fragment size, patients were separated into two groups. Group 1 was consisted of posterior fragment size smaller than $15 \%$ and group 2 was bigger than $15 \%$ due to CA3DM.

Results: The interobserver correlation (IOC) between two observers and CA3DM was 44.3\%. Also the IOC between first observer and CA3DM was 35.7\% ( $p<0.05)$, second observer and CA3DM were $46.6 \%(p<0.01)$ and observers was $51.6 \%$ ( $<<0.01)$. For group 1, IOC between two observers and CA3DM was $41.2 \%(\mathrm{p}<0.05)$ first observer and CA3DM was 30.6\% (p>0.05), second observer and CA3DM was 51.6\% ( $<<0.05)$ and two observers were $45.8 \%(p<0.05)$. For group 2, IOC between two observers and CA3DM was $27.9 \%(p>0.05)$ first and CA3DM was $18.6 \%(\mathrm{p}>0.05)$, second observer and CA3DM was $7.1 \%(\mathrm{p}>0.05)$ and two observers was $49 \%(\mathrm{p}<0.05)$.

Conclusion: Our study shows that posterior malleolar fragment size measuring on plain radiography is not a safe method for bigger fragments and CA3DM method may be a more reliable to assess correct fragment size and also to analyze fracture morphology. But for fragments $\leq 15 \% \mathrm{CA} 3 \mathrm{DM}$ and plain radiographic measures are no statistically different.

Key words : ankle fractures, posterior malleolar fractures, trimalleolar fractures.

Öz

Amaç: $\mathrm{Bu}$ çalışmanın amacı, posterior malleol fragman (PMF) boyutunun ayak bileği lateral grafisi üzerinden ölçüm ve bilgisayar destekli 3D modelleme (BD3DM) yöntemleri kullanılarak boyutlarının karşılaştırılmasıdır. Yöntemler: Ocak 2015 ve kasım 2018 yılları arasında posterior malleol kırı̆̆ı olan 51 hasta çalışmaya dahil edildi. PMF boyutunun distal tibia eklem yüzeyine oranı iki farklı yöntem ile ve iki cerrah tarafindan hesaplandı. Posterior fragman boyutuna göre hastalar iki gruba ayrıldı. BD3DM yöntemine göre group 1 PMF boyutu \% 15 'ten küçük ve group $2 \% 15$ 'ten büyük olanlardan oluşmaktaydı.

Bulgular: İki cerrah ve BD3DM arasında interobserver uyum \% 44.3, birinci cerrah ve BD3DM \% 35.7 $(\mathrm{p}<0.05)$, ikinci cerrah ve BD3DM \% $46.6(\mathrm{p}<0.01)$ ve iki cerrah ile \% $51.6(\mathrm{p}<0.01)$ idi. Birinci grupta iki cerrah ve BD3DM arasındaki uyum \% $41.2(\mathrm{p}<0.05)$ ve birinci cerrah ile BD3DM arasında ise \%30.6 $(\mathrm{p}>0.05)^{\circ}$ idi. İkinci cerrah ve BD3DM arasındaki uyum \% $51.6(\mathrm{p}<0.05)$ ve iki cerrahın kendi aralarındaki uyumu \% 45.8 $(\mathrm{p}<0.05)^{6}$ idi. İkinci grupta iki cerrah ve BD3DM arasindaki uyum \% 27.9 ( $\left.>0.05\right)$ ve birinci cerrah ile BD3DM arasında ise \%18.6 ( $>0.05)^{`}$ idi. İkinci cerrah ve BD3DM arasındaki uyum \%7.1 ( $\left.>>0.05\right)$ ve her iki cerrahın kendi aralarındaki uyumu \%49 $(\mathrm{p}<0.05)$ olarak bulundu.

Sonuç: Çalışmamız göstermiş̧ir ki posterior malleol fragmanın radiografik yöntemle ölçümü $>\% 15$ 'ten büyük fragmanlar için güvenilir bir yöntem değildir. BD3DM yöntemi ise gerçek fragman boyutunu hesaplamada güvenilir bir yöntemdir. Fakat $\leq \% 15$ ’ten küçük fragmanlar için iki yöntem arasında istatistiksel fark saptanmamıştır.

Anahtar Kelimeler: ayak bileği kırığı, posterior malleol kırığı, trimalleol kırığı.
${ }^{1}$ University of Health Sciences, Umraniye Training and Research Hospital, Department of Orthopedics and Traumatology, Istanbul, Turkey.

${ }^{2}$ Gumushane University, Department of Geometric Engineering, Gumushane, Turkey. ${ }^{3}$ Yildiz Technical University, Department of Geomatic Engineering, Istanbul, Turkey. ${ }^{4}$ Intercontinental Hisar Hospital, Department of Orthopedics and Traumatology, Istanbul, Turkey.

(iD

GA: $0000-0002-0669-8070$

HÇR: 0000-0003-2696-2446

BB: $0000-0002-4248-116 \mathrm{X}$

GS: $0000-0002-9474-112 X$

Ethics Committee Approval: The study was approved by the local ethical authority (Project No: 2017-1794)

Etik Kurul Onayı: Çalışma lokal etik komite tarafindan onaylanmıștır (Proje No: 2017-1794).

Conflict of Interest: No conflict of interest was declared by the authors.

Çıkar Çatışması: Yazarlar çıkar çatışması bildirmemişlerdir.

Financial Disclosure: The authors declared that this study has received no financial support.

Finansal Destek: Yazarlar bu çalışma için finansal destek almadıklarını beyan etmişlerdir.

Geliş Tarihi / Received: 01.11.2019

Kabul Tarihi / Accepted: 23.02.2020

Yayın Tarihi / Published: 20.03.2020

Sorumlu yazar / Corresponding author:

Güray Altun

Adres/Address: University of Health Sciences Umraniye Training and Research Hospital, Department of Orthopedics and Traumatology, Istanbul, Turkey.

e-posta: gurayaltun@hotmail.com

Tel/Phone: +90 5057456667

Copyright $(\mathcal{C}$ ACEM 


\section{Introduction}

Posterior malleolar fractures range from small extraarticular lip fractures to large triangular fragments, extending to the medial and/or lateral malleolus. These fractures generally occur as a result of rotational trauma and account for approximately $7 \%$ of all ankle fractures [1]. Less satisfactory outcomes are generally seen in ankle fractures that include a posterior malleolar fragment, compared to uni or bimalleolar fractures [2, 3]. The treatment steps of lateral and medial malleolar fractures are clear but the method to be employed in posterior malleol fractures is still a matter of debate.

A recent study recommended surgical anatomic reduction for PMF of a size $>10 \%$ of the articular surface [4]. However, other authors have suggested that only fragments $>25$ $33 \%$ and $2 \mathrm{~mm}$ displaced fragments should be treated with surgical fixation $[5,6]$. There is no consensus in literature regarding the optimal treatment of PMF. The most significant reason for the controversy is the estimation of PMF size from two plain radiographs. A previous radiology-based study suggested that plain radiographs were unreliable for the analysis of PMF size [7]. Recent studies have shown that measuring fragment size on a lateral ankle radiograph was not compatible with computed tomography (CT) images $[8,9]$. With CT scans, preoperative fragment sizing is easier and postoperative reduction quality can also be checked. Nevertheless, many surgeons decide which treatment to apply to posterior malleolus fractures without examining CT images. But these studies are independent of the fragment sizes. For bigger sized fragments $\mathrm{CT}$ images may be the exact viewing method but for smaller fragments is not clear yet.

The aim of this study is to compare the measurements of posterior malleolar fragment (PMF) size measured on lateral ankle plain radiography and computer-assisted 3D modelling (CA3DM) based on computed tomography (CT) views according to fragment size.

\section{Material and methods}

This research has been approved by the IRB of the authors' affiliated institutions. The study was conducted according to the principles described in the Declaration of Helsinki. Written informed consent was obtained from all study participants.

Retrospective evaluation was made of 75 patients who presented at the Emergency Department with tri-malleolar fractures with PMF, between January 2015 and November 2018. Inclusion criterias were patients with ankle fractures involved posterior malleol fragment, older than 18 years, proper images on radiological database for measurement. Exclusion criterias were ankle osteoarthritis, congenital or acquired ankle deformities, history of ipsilateral ankle surgery. According to posterior fragment size ratio to distal tibia articular surface, patients were separated into two groups. Group 1 was consisted of posterior fragment size smaller than $15 \%$ and group 2 was bigger than $15 \%$ due to CA3DM. All computer assisted values were compared to two surgeons" manual values for both group.

\section{Radiological Evaluation}

Measurements were evaluated on standard lateral ankle radiographs on which the posterior portion of the distal tibia was superimposed on the distal fibula and both talar domes were superimposed allowing for adequate inspection of the superior articular surface of the talus. All radiographs were obtained on the same digital radiography device (Siemens Axiom Aristos VX, Germany) and CT images were acquired using Siemens
SOMATOM Sensation 16 or 64 scanners at a slice thickness of 4 $\mathrm{mm}$ and an average in-plane $(\mathrm{x}-\mathrm{y})$ resolution of 0.72 pixels.

\section{Radiological Measuring Process}

The PMF ratio was measured with the 2 plain radiographs of the lateral ankle method by fifteen year experienced two senior orthopedic and trauma surgeons using $\mathrm{a} / \mathrm{b}$ (a:posterior malleolar fragman articular surface, b:distal tibia articular surface) formula (Figure 1. Ankle CT images were uploaded to 3D-Doctor software (Able Software Corp, Lexington, MA, USA) and the PMF surface ratio was measured by a specialist topographic engineer (Table 1,2). The medical images were stored in ".dcm (DICOM)" format. In the first step, pre-processing consisted of filtering steps for noise removal, and then in the second step, segmentation was used to differentiate bone tissue from other tissues. A region growing method was applied on the CT images, using Hounsfield Units. The noise was brought about after this interactive method was applied and the results were manually edited. Thus, the results were obtained in the present study and 3D distal tibia articular surface models were then created using 3D-Doctor software. Parts a (posterior fragment area) and b (distal tibia articular area) were saved in separate layers, thereby eliminating textural errors. Finally, biometric measurements were made on the $3 \mathrm{D}$ model. The measurement samples are shown in Figure 2.

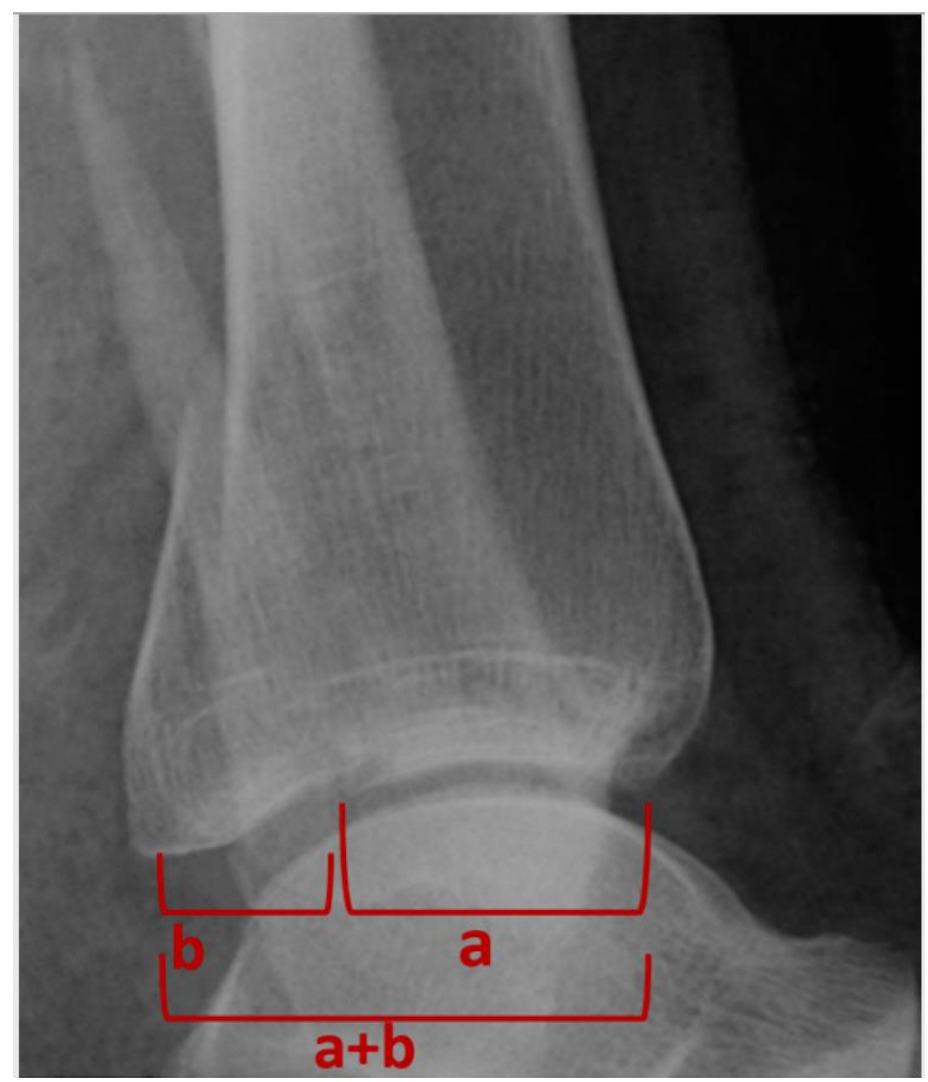

Figure 1: posterior malleolar fragment size measurement on plain radiograph.

$\mathrm{a}+\mathrm{b}$ : total ankle articular size, b: posterior malleolar fragment articular size. 


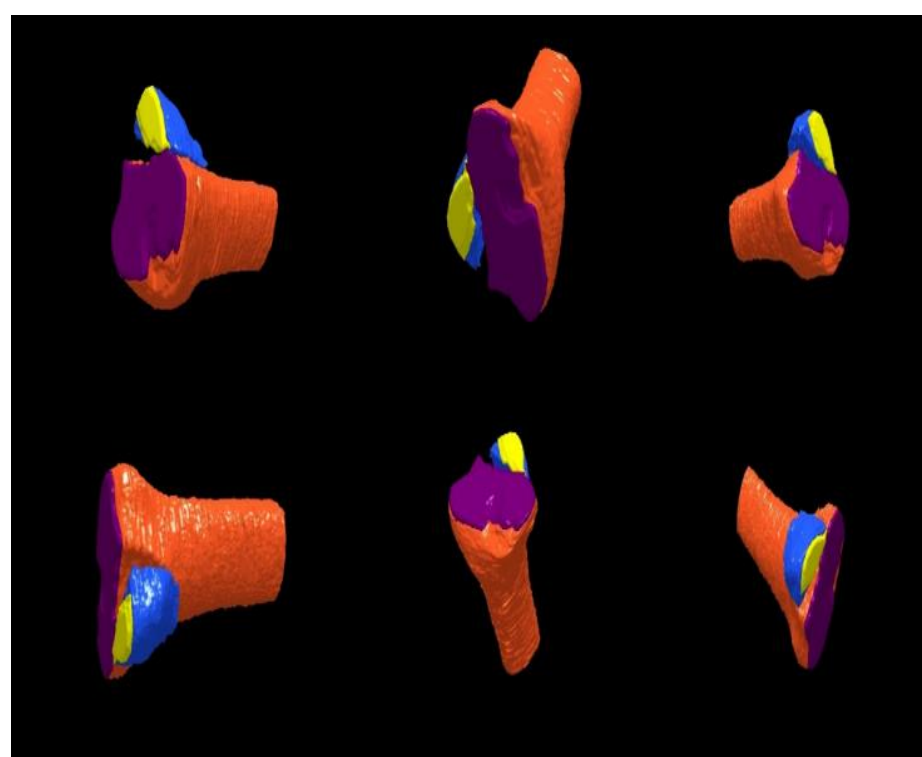

Figure 2: CA3DM images obtained via 3D-Doctor software.

yellow: posterior malleolar fracture articular side, purple: ankle articular side, orange: non-articular tibial surface, blue: non-articular fragment surface.

\section{Statistical Analysis}

Data obtained in the study were analysed statistically using NCSS (Number Cruncher Statistical System) 2007 software (Kaysville, Utah, USA). During the evaluation of the study data, descriptive statistical methods (Mean, Standard Deviation, Median, Minimum, and Maximum) were used. Bland Altman Graphics was used for the in-group comparisons of the variables without normal distribution. Intraclass Correlation Coefficient (ICC) (Table 3) was used for evaluation of pairwise agreement between radiography and CT scan. A value of $p<0.05$ was considered statistically significant.

\section{Results}

A total of 24 patients were excluded: 3 patients with ankle osteoarthritis, 4 with congenital or acquired ankle deformities, 3 with a history of ipsilateral ankle surgery, 3 with poor quality radiographs on which fragment size could not be measured, 6 aged $<18$ years and 5 with missing proper CT images. Thus, the study included a final total of 51 patients, comprising 29 males and 22 females with a median age of 42.4 years (range, 19-54 years). Fracture of the right-side extremity was determined in 21 patients and the left in 30 . The mechanism of trauma was traffic accident in 9 cases, sports accident in 17, a fall from height in 18 and a bicycle accident in seven.

The IOC between two observers and CA3DM was $44.3 \%$ (fair, $\mathrm{p}>0.05$ ), first observer and CA3DM was $35.7 \%$ (poor, $\mathrm{p}<0.05$ ), second observer and CA3DM was $46.6 \%$ (fair, $\mathrm{p}<0.01$ ) and two observers was $51.6 \%$ (fair, $\mathrm{p}<0.01$ ).

Group 1 (22 patients)

The IOC between two observers and CA3DM was 41,2 (fair,p>0.05) first observer and CA3DM was $30.6 \%$ (poor,p $>0.05$ ) second observer and CA3DM was $51,6 \%$ (fair,p<0.05) and between the two observers was 45,8 (fair, $\mathrm{p}<0.05)$

Group 2 (29 patients)

The IOC between two observer and CA3DM was 27,9\%, (poor, $p>0.05$ ) for the first observer and CA3DM was $18.6 \%$ (poor, $\mathrm{p}>0.05$ ), for the second observer and CA3DM was $7.1 \%$ (poor, $p>0.05$ ) two observers was $49 \%$ (fair, $p>0.05$, $\mathrm{p}<0.05$ ) (Tables 3, 4).
Table 1 : The posterior malleol fragment measurements via 3D computer-assisted program and the measurements of the observers taken on plain radiographs about group 1 .

\begin{tabular}{llcc} 
Group 1 & $\begin{array}{l}\text { a/b\# } \\
(\%)\end{array}$ & $\begin{array}{c}\text { First observer } \\
(\%)\end{array}$ & $\begin{array}{c}\text { Second observer } \\
(\%)\end{array}$ \\
\hline 1 & 8 & 8 & 12 \\
2 & 9 & 8 & 11 \\
3 & 12 & 13 & 10 \\
4 & 12 & 11 & 13 \\
5 & 12 & 13 & 11 \\
6 & 12 & 14 & 10 \\
7 & 12 & 11 & 15 \\
8 & 12 & 15 & 14 \\
9 & 12 & 14 & 14 \\
10 & 12 & 12 & 12 \\
11 & 13 & 14 & 13 \\
12 & 13 & 17 & 13 \\
13 & 13 & 14 & 15 \\
14 & 13 & 12 & 13 \\
15 & 14 & 14 & 14 \\
16 & 14 & 14 & 17 \\
17 & 14 & 13 & 15 \\
18 & 15 & 12 & 15 \\
19 & 15 & 11 & 13 \\
20 & 15 & 13 & 11 \\
21 & 15 & 14 & 15 \\
22 & 15 & 10 & 12
\end{tabular}

\#: measured with CA3DM, a/b: fragment ratio to the ankle articular surface, a: posterior fragment articular area, b: distal tibia articular surface area.

Table 2 : The posterior malleol fragment measurements via 3D computer-assisted program and the measurements of the observers taken on plain radiographs about group 2 .

\begin{tabular}{llcc} 
Group 2 & $\begin{array}{l}\text { a/b\# } \\
(\%)\end{array}$ & $\begin{array}{c}\text { first observer } \\
(\%)\end{array}$ & $\begin{array}{c}\text { second observer } \\
(\%)\end{array}$ \\
\hline 1 & 16 & 18 & 20 \\
2 & 16 & 23 & 24 \\
3 & 16 & 19 & 17 \\
4 & 17 & 21 & 19 \\
5 & 17 & 14 & 15 \\
6 & 18 & 18 & 19 \\
7 & 18 & 11 & 14 \\
8 & 18 & 17 & 22 \\
9 & 19 & 17 & 20 \\
10 & 19 & 16 & 17 \\
11 & 19 & 22 & 24 \\
12 & 20 & 24 & 23 \\
13 & 20 & 23 & 20 \\
14 & 21 & 19 & 21 \\
15 & 21 & 24 & 23 \\
16 & 22 & 18 & 19 \\
17 & 22 & 26 & 28 \\
18 & 22 & 2 & 22 \\
19 & 22 & 23 & 21 \\
20 & 24 & 29 & 30 \\
21 & 25 & 22 & 23 \\
22 & 25 & 27 & 29 \\
23 & 26 & 29 & 30 \\
24 & 26 & 19 & 23 \\
25 & 26 & 26 & 24 \\
26 & 27 & 30 & 29 \\
27 & 28 & 24 & 24 \\
28 & 28 & 22 & 22 \\
29 & 28 & 25 & \\
\hline
\end{tabular}

\#: measured with CA3DM, a/b: fragment ratio to the ankle articular surface, a: posterior fragment articular area, b: distal tibia articular surface area. 
Table 3: Intraclass correlation coefficient (ICC) table.

\begin{tabular}{ll} 
ICC & Result \\
\hline$\leq 0.40$ & Poor \\
$0.40-0.59$ & Fair \\
$0.60-0.74$ & Good \\
$0.75-1.00$ & Excellent
\end{tabular}

Table 4: The statistical comparisons of the observer measurements and CA3DM results.

\begin{tabular}{llccc} 
& & \multicolumn{3}{c}{ Values } \\
\cline { 3 - 5 } & & $\begin{array}{c}\text { total } \\
(\mathrm{n}=51)\end{array}$ & $\begin{array}{c}\text { group 1 } \\
(\mathrm{n}=22)\end{array}$ & $\begin{array}{c}\text { group 2 } \\
(\mathrm{n}=29)\end{array}$ \\
\hline 3DCAM & Min-Max & $0.087-0.289$ & $0.087-0.168$ & $0.175-0.289$ \\
& Median) & $(0.168)$ & $(0.14)$ & $(0.225)$ \\
& Mean \pm SD & $0.18 \pm 0.05$ & $0.14 \pm 0.03$ & $0.22 \pm 0.04$ \\
Observer 1 & Min-Max & $0.08-0.37$ & $0.08-0.37$ & $0.08-0.29$ \\
& (Median) & $(0.16)$ & $(0.14)$ & $(0.19)$ \\
& Mean \pm SD & $0.16 \pm 0.07$ & $0.15 \pm 0.07$ & $0.18 \pm 0.06$ \\
Observer 2 & Min-Max & $0.1-0.3(0.17)$ & $0.1-0.24$ & $0.13-0.30$ \\
& (Median) & & $(0.14)$ & $(0.19)$ \\
& Mean \pm SD & $0.17 \pm 0.05$ & $0.16 \pm 0.05$ & $0.20 \pm 0.05$ \\
& $\mathrm{p}$ & 0.567 & 0.819 & 0.327 \\
3DCAM & ICC & 0.443 & 0.412 & 0.279 \\
Observer 1 & p & 0.357 & 0.306 & 0.186 \\
3DCAM & ICC & 0.029 & 0.125 & 0.262 \\
Observer 2 & $\mathrm{p}$ & 0.466 & 0.516 & 0.071 \\
Observer 1 & ICC & 0.005 & 0.020 & 0.404 \\
Observer 2 & $\mathrm{p}$ & 0.516 & 0.458 & 0.490 \\
\hline
\end{tabular}

SD: standard deviation, ICC:Intraclass Correlation Coefficient,

p:Friedman test.

\section{Discussion}

The discussion around posterior malleolus treatment is currently a "trend topic". In cases with trimalleoler fracture, deciding the posterior malleol fragment size with plain radiography alone can lead to misdiagnosis and incorrect treatment mistakes. Nevertheless, measuring fragment size on plain radiographs of the lateral ankle is still the leading option in treatment decisions.

In this study, PMF size was assessed with lateral ankle plain radiograph and the CA3DM technique. The results of these two measurements were incompatible, and the values measured by two surgeons using the 2-dimensional method were also incompatible. The inconsistency between the two methods was higher in group two. This could be attributed to the fact that smaller fragments are more linear resulting in shelf-type fractures, whereas bigger fragments are more irregular. However, interestingly this incompatibility was surgeon independent in respect of fragment size as in larger fragments the congruence between surgeons was $49 \%$ and for the smaller fragments, it was $45.8 \%$. But for smaller fragments the size of the posterior malleol was not significantly different between two imaging methods.

Apart from sizing the PMF, Haraguchi $(\mathrm{H})$ and Bartonicek (B) classified these fractures in respect of morphological properties $[10,11]$. Although the two classifications of $\mathrm{H}$ type 3 and $\mathrm{B}$ type 1 are similiar, the $\mathrm{B}$ classification is more comprehensive as it includes whether or not the fracture line extends to the fibular notch, the PMF height and talar dis/subluxation. In the current series, B type 2 and 3 were determined at higher rates, which was consistent with the findings of Bartonicek's own series.

Fractures with PMF tend to have a poorer prognosis than those without a posterior fragment and thus PMF can be seen as a negative prognostic factor $[2,12,13]$. This may be due to chondral cellular damage or intra-articular fragments that cannot be determined during surgery [14]. Recent studies have shown that intra-articular impaction and fragmentation seem to be more important than fragment size $[15,16]$. This cannot be verified on plain radiographic images and it is difficult to determine the morphology and fracture pattern of PMF for bigger fragments.

Recent studies have shown incompatibility between observers in respect of PMF size on lateral ankle radiographs and this dilemma has forced the surgeons to better understand the accurate sizing and morphology of PMF [7, 17-19]. In the literature, fragment sizing methods are divided into two sections; the assessment of fragment size from plain radiography measurements and CT-based studies [8, 20]. Plain radiography studies have demonstrated poor technique accuracy and interobserver reliability in the visualisation of fragment size. Accurate assessment of articular involvement of the PMF in ankle fractures is mandantory, in addition to comminution and impaction.

Ebrahim Nabil et al. [17] reported that the problem of the distal fibula superimposed on the PF on the ankle lateral radiograph, could be eliminated with $50^{\circ}$ external rotation. In a sawbone study by Gonzalez et al. [20], it was shown that a radiograph of the ankle in $20^{\circ}$ external rotation would be more helpful in the evaluation of fragment size and displacement. However, the superpositioning of the distal fibula on the lateral radiograph represents the most significant drawback in the evaluation of posterior malleolar fractures. As these fractures show different morphologies according to the mechanism of formation, it is difficult to define a standard position for the taking of radiographs. In contrast, sufficient information may be obtained about both the fragment morphological structure and intra-articular displacement from measurements taken on CT images. All the patients in the current study were also evaluated with ankle CT.

In a study by Evers et al [21], fragments $<25 \%$ were shown to cause later osteorthritis in the ankle, as was also reported in the study by Langenhuisen et al [4]. However, as the measurement in the Langerhuisen study [4] had been made with the single plane radiographic method, the interobserver reliability was low, leaving these results open to debate. Although the Julia et al study was supported by CT, the medial malleolar joint surface measurements were not included. In the current study, imaging was performed including all the distal tibia joint surface fracture fragments, because it was thought that not evaluating all the distal tibia joint surfaces in posterior malleolar fractures showing extension to the medial malleolus, such as in B type 3-4 and $\mathrm{H}$ type 2, would prevent the accurate calculation of the joint surface area of both the whole ankle joint and the fracture fragments.

This radiology-based study has to be discussed in the light of its strengths and limitations. The primary limitation was the low number of patients, and the results were not supported with patient clinical information. However, strong aspect of the study can be said to to be the assessment of fracture size from plain radiographs by two surgeons and that these results were compared with CA3DM. Previous studies have indicated that evaluating PMF size and morphology is more accurate with CT images but the current study is alike in respect of viewing fracture size via the 3D imaging system measurements and taking attention to smaller fragments measurement accuracy using plain radiography.

In conclusion, while evaluating the treatment of trimalleoler fractures, PMF sizing is essential but estimating PMF using plain radiographic images is not a safe method. For 
reliable evaluations, CA3DM or similiar 3D-based measurement methods should be applied specifically for fragments $>15 \%$. But for fragments $\leq 15 \%$, CT and plain radiographic measures are not significantly different. This study may be helpful in decisionmaking before discussing treatment choices for ankle fractures with posterior fragment involvement and for smaller fragments complicated imaging methods can be eliminated.

\section{References}

1. Court-Brown CM, McBirnie J, Wilson G. Adult ankle fractures - an increasing problem? Acta Orthop Scand. 1998;69:43-7.

2. Jaskulka RA, Ittner G, Schedl R. Fractures of the posterior tibial margin: their role in the prognosis of malleolar fractures. J Trauma. 1989;29:1565-70.

3. McDaniel WJ, Wilson FC. Trimalleolar fractures of the ankle. An end result study. Clin Orthop Relat Res. 1977;122:37-45.

4. Langenhuijsen JF, Heetveld MJ, Ultee JM. Results of ankle fractures with involvement of the posterior tibial margin. J Trauma. 2002;53:55-60.

5. Van den Bekerom MP, Haverkamp D, Kloen P. Biomechanical and clinical evaluation of posterior malleolar fractures. A systematic review of the literature. J Trauma. 2009;66:279-84.

6. Abdelgawad AA, Kadous A, Kanlic E. Posterolateral approach for treatment of posterior malleolus fracture of the ankle. J Foot Ankle Surg. 2001;50:607-11.

7. Ferries JS, DeCoster TA, Firoozbakhsh KK, Garcia JF, Miller RA. Plain radio $\neg$ graphic interpretation in trimalleolar ankle fractures poorly assesses posterior fragment size. J Orthop Trauma. 1994;8:328 31.

8. Büchler L, Tannast M, Bonel HM, Weber M. Reliability of Radiologic Assessment of the Fracture Anatomy at the Posterior Tibial Plafond in Malleolar Fractures, J Orthop Trauma. 2009;23:208-12.

9. de Muinck Keizer RO, Meijer DT, van der Gronde Ba, Teunis T, Stufkens SA, Kerkhoffs GM, Goslings JC, Doornberg JN. Articular Gap and Step off Revisited: 3D Quantification of Operative Reduction for Posterior Malleolar Fragments. J Orthop Trauma. 2016;30:670-5.

10. Haraguchi N, Haruyama H, Toga H, Kato F. Pathoanatomy of posterior malleolar fractures of the ankle. J Bone Joint Surg Am. 2006;88:1085-92.

11. Bartoníček J, Rammelt S, Kostlivý K Vaněček V, Klika D, Trešl I. Anatomy and classification of the posterior tibial fragment in ankle fractures, Arch Orthop Trauma Surg. 2015;135:505-16.

12. Tejwani NC, Pahk B, Egol KA. Effect of posterior malleolus fracture on outcome after unstable ankle fracture. J Trauma. 2010;69:666-9.

13. Odak S, Ahluwalia R, Unnikrishnan P, Hennessy M, Platt S. Management of posterior malleolar fractures: a systematic review. J Foot Ankle Surg. 2016;55:140-5.

14. Ono A, Nishikawa $S$, Nagao A, Irie $T$, Sasaki $M$, Kouno $T$. Arthroscopically assisted treatment of ankle fractures: arthroscopic findings and surgical outcomes. Arthroscopy. 2004;20:627-31.

15. Drijfhout van Hooff CC, Verhage SM, Hoogendoorn JM. Influence of Fragment Size and Postoperative Joint Congruency on Long-Term Outcome of Posterior Malleolar Fractures, Foot Ankle Int. 2015;36:673-8.

16. Gardner MJ, Streubel PN, McCormick JJ, Klein SE, Johnson JE, Ricci WM. Surgeon practices regarding operative treatment of posterior malleolus fractures. Foot Ankle Int. 2011;32:385-93.

17. Ebraheim NA, Mekhail AO, Haman SP. External Rotation-Lateral View of the Ankle in the Assessment of the Posterior Malleolus Foot Ankle Int. 1999;20:379-83.

18. Meijer DT, Doornberg JN, Mallee WH, van Dijk CN, Kerkhoffs GM, Stufkens SA. Guesstimation of posterior malleolar fractures on plain lateral radiographs. Injury. 2015;46:2024-9.

19. Miniaci-Coxhead SL, Martin EA, Ketz JP. Quality and utility of immediate formal postoperative radiographs in ankle fractures. Foot Ankle Int. 2015;36:1196-201

20. Gonzalez O, Fleming JJ, Meyr AJ. Radiographic assessment of posterior malleo $\neg$ lar ankle fractures. $\mathrm{J}$ Foot Ankle Surg. 2015;36:1196-201.

21. Evers J, Barz L, Wähnert D, Grüneweller N, Raschke MJ, Ochman S. Size matters: The influence of the posterior fragment on patient outcomes in trimalleolar ankle fractures Injury. 2015;46:S109-13. 